\title{
Integrating Cultural Materials as the Media for Extensive Reading for Teaching Bahasa Indonesia as Foreign Language
}

\author{
Mohamad Isnaini a,1, Faizin ${ }^{\mathrm{b}, 2}$, Rochmatika Nur Anisa ${ }^{\mathrm{c}, 3}$ \\ abc Universitas Muhammadiyah Malang, Jalan Raya Tologomas 246 Malang, 65145, Indonesia \\ ${ }^{1}$ m.isnaini@umm.ac.id; ${ }^{2}$ fayzumm@umm.ac.id; ${ }^{3}$ rochmatikanuranisa@umm.ac.id \\ * Corresponding Author
}

\begin{tabular}{l}
\hline INFO ARTIKEL \\
\hline Sejarah Artikel: \\
Diterima: 1 Maret 2021 \\
Direvisi: 23 Maret 2021 \\
Disetujui: 4 April 2021 \\
Tersedia Daring: 10 April 2021 \\
\hline Kata Kunci: \\
BIPA
\end{tabular}

\section{ABSTRAK}

Menyajikan teks Bahasa Indonesia yang ditulis dengan meintegrasikan unsur-unsur budaya untuk materi belajar siswa Bahasa Indonesia bagi Penutur Asing (BIPA) memberikan banyak manfaat. Selain sebagai sarana untuk meningkatkan jumlah kosa kata, materi yang memasukkan unsur-unsur budaya juga menjadi media untuk mempromosikan budaya Indonesia. Melalui pertimbangan pada kebutuhan belajar siswa BIPA di mana harus memasukkan pembelajaran budaya lokal, penyajian teks

Membaca Ekstensif

Materi Kebudayaan bacaan ini dapat dilakukan secara insidental maupun secara langsung dengan menggunakan model membaca ekstensif. Oleh karena itu, penyusanan materi yang mengintegrasikan unsur budaya sangat direkomendasikan untuk dipilih oleh guru karena membantu siswa BIPA dalam mempelajari prinsip-prinsip yang menarik dan otentik. Pada artikel ini, data diambil dari berbagai penelitian terdahulu yang mencakup penyusunan teks berbasis interkultural, model pembelajaran BIPA, dan berbagai jenis model membaca ekstensif. Data diolah secara deskriptif untuk dapat melahirkan gagasan baru tentang penyusunan bahan ajar sebagai materi pendukung proses belajar mengajar di kelas BIPA. Sebagai hasil dari penelitian ini adalah pengajar BIPA diharapkan dapat menyusun teks bacaan yang memiliki kesamaan topik untuk selanjutnya dapat diimbuhkan dengan latihan praktik. Penyusunan buku teks dengan menitikkberatkan konten berbasis budaya dan dikelompokkan sesuai dengan tingkat kemahiran berbahasa juga dapat meningkatkan kemampuan berpikir kritis bagi para siswa BIPA.

\begin{tabular}{ll}
\hline & ABSTRACT \\
\hline Keywords: & Presenting Indonesian text written by combining cultural elements for \\
BIPA & student learning materials of Indonesian for Foreign Speakers (BIPA) \\
Extensive Reading & provides many benefits. Apart from being a stimulation to enrich \\
Cultural Materials & vocabulary, material that contains cultural elements is also a means to \\
& students who must include local cultural learning, the presentation of this \\
& reading text can be done incidentally or directly by using an extensive \\
reading model. Therefore, it is suggested that teachers choose a material \\
that integrates cultural elements since it beneficial for BIPA students to \\
learn interesting and authentic principles. In this article, data is drawn \\
from various previous studies which include compilation of intercultural \\
based texts, BIPA learning models, and various types of extensive reading \\
models. The data is processed descriptively to be able to generate new \\
ideas about the preparation of teaching materials as expected to support \\
the teaching and learning process in BIPA classes.
\end{tabular}



Media for Extensive Reading for Teachnig Bahasa Indonesia as Foreign Language. Satwika : Kajian Ilmu Budaya dan Perubahan Sosial, 5(1) 131-141. doi: 10.22219/satwika.v5i1.15851

\section{Introduction}

Classroom activities that discuss the issue of diversity and inclusion are becoming more relevant as a result of ongoing globalisation; one of those issues is literacy. In recent decade, literacy is being one prominent issue on education field. Literacy is defined by UNESCO as the ability to understand, interpret, create, communicate and computerize the written materials associated with varying context. Specifically, literacy means someone's ability to read and write. Indonesia initiates a specific program to sustain and meet the requirements of the quality of Indonesian literacy, namely National Literacy Movement $(G L N)$. It becomes a role model in activating reading habit at schools. GLN's framework enables to be adopted in teaching and learning model in Indonesia for Foreign Language (BIPA) with some adjustments.

The growth of the communicative approach to language learning is the authentic topic explored in the BIPA learning model. This highlights the value of bringing culture into language learning as well as the role of culture as an interconnected aspect of language. In addition, reading is divided into two types, intensive and extensive reading (Ghanbari \& Marzban, 2014). Intensive Reading (IR) refers to the practice of particular reading skill to know the linguistic study in a certain text. Moreover, its aim is helping a student to obtain the detail meaning from a text (Renandya, 2007). Having different perspective, the Extensive Reading (ER) is the more joyful activity in reading. The students are allowed to determine kinds of reading sources. In line with this, ER's approach is to teach and learn of reading in large quantities of materials. It can expose amount of meaningful input.

In addition, Renandya and Chang (2017) reported that $68.9 \%$ Asia students improved in reading skill and $82.4 \%$ increased in overall English language proficiency since they did ER in the school activities. More specific, 20\% Indonesia students gained reading and English language proficiency properly. Since ER permits students to choose any books to read, Renandya et al., (2018) came with the potential of narrow reading in the ER to lead students enhancing learner's general language competence. The narrow reading is possible by means of a series of books. The series of books is defined by Barnett \& Krashen (2004) as several books which written by an author or about a single topic. Moreover, narrow reading facilitates the exposure to amount of vocabularies used in certain topics (Krashen, 2004). Hansen \& Collins (2015) added the series reading books were very popular because these books contained highly familiar language, were easy to follow, and had relatable characters. After doing ER series of books gradually, the readers are possible to expand their reading topics. Based on the background, the narrow reading a series of books which is written by BIPA teachers is possible to improve the literacy skill of BIPA students in Indonesia.

Most of the teachers believe that selfselected reading materials influence the students' language development. Renandya et al., (2018) mentioned that reading was an excellent way of developing students' literacy and language skills which had been proven in many studies. One of the studies from Krashen (2004) showed that regular 
reading books or any sources based on the self-selected also helped acquire language proficiency. Self-selected material reading includes to the concept of ER in which readers are permitted to read a variety of material. Grabe and Stoller (Kiyomi et. al., 2018) defined ER as the teaching and learning approach that made the students read large quantities of materials. ER takes a role as the prominent method that provides students with Indonesian language vocabulary input in various contexts. ER also assigns students to repeat linguistics form, such as vocabulary or structure sentence. Since ER gives opportunity to students read many materials, Krashen (2004) came up with the idea of narrow reading. As the part of ER, narrow reading is possible to control the number of linguistics input to students. Moreover, it may be that narrow reading is more efficient for second language learners.

As mentioned in the previous, narrow reading gives the scope for students to select the reading materials. Scoping the reading materials is by purpose to lead students to focus on one author or in a certain interest topic. In accordance to that idea, narrow reading can help students to comprehend context in a certain book because students can learn distinctive expressions or style of each author. Narrow reading also contributes to students in deeply conquering certain topic in self-selected materials for reading. In addition, Krashen (2004) mentioned that narrow reading had potential to be a motivation of students to read.

In agreement with the theory of narrow reading, a series of books becomes one particular type of recommended books for the students. Renandya et. al., (2018) declared that reading a series book became an interesting activity. Students who read a series of books reported that they had the habit to read gradually. Characters in a series book are possible to be a distinctive point that cannot be provided in others books. Renandya et. al., (2018) added that a series of book highly motivated students to reach the language to be exciting and rewarding to them. A series of books as the great source of narrow reading facilitates language development. Familiarity with the language and writing style of certain author makes the reading is enjoyable.

Considering the BIPA students diverse language needs, using the book which teach and assist the students to improve their communication skills including critical thinking, intercultural accomplishment as well as cultural willingness becomes a crucial issue. Cultural willingness defines as the reaction of the students in broadening their understanding, improving sensitivity and promoting flexibility in cultural diversity.

As mentioned by Reimann (2009), most of language learning context limited its activity. The students will only learn a language based on the book guidance. It has been problematic especially while deciding whose and which culture should be represented. Using the book which contains local culture will assist the students to enrich their knowledge about certain culture. In this case, BIPA students will learn more about Indonesia by reading a text which was integrated by diverse cultures. As most language learning settings are restricted to classroom activity, it is an essential way to provide missing element of realism as accurately and objectively as possible through the reading text.

Over the past decades, the concept of intercultural does not only involve the theoretical landscape. The authentic subject discussed in the BIPA learning model corresponds to the growth of the communicative approach to language learning. This demonstrates the importance of integrating culture into language learning and the significance of culture as an interconnected part of language. In many researches, intercultural elements develop into the practical issues. According to (Romijn et al., 2020) intercultural issues are the way of someone to explain their experience and engagement with cultural differences and how they gain the ability to create experiences that match people from 
another culture. Furthermore, intercultural concepts that focus more directly on the school context are culturally responsive teaching, which can be defined as "using the cultural knowledge, prior experiences, frames of reference, and performance styles of ethnical diverse students to make learning encounter more relevant to and effective for them" (Romijn et al., 2020).

In current study, intercultural concept matches to adapt and implement in BIPA class. Cultural material plays an important role not only in the macro-contexts of people and countries but also in the micro-contexts of actual intercultural interactions which is demonstrated clearly. BIPA is a multicultural classroom where there are many students which have different cultural backgrounds. In order to be relevant and capture students' interest, the way of using book should be converted to the digital platform. In considering the implementation of a viable and appropriate cultural awareness in this book, teacher needs to focus on primary concern that involves the content, usage, and goal of texts and materials.

According to Cunningsworth's theory (1995) about developing material in course book, it is compulsory to provide integrated package of materials consisting of themes, topic, communicative, cultural issues, and the actual items of language such as vocabulary, grammar, and phonology. In accordance to the theory, this research adopted those aspects to develop a series of reading text materials which integrates cultural aspects. Since students cannot handle those language aspects in the beginning state of learning foreign language, evaluating content in a series of intercultural reading text is recommended to help teachers give variety in BIPA class. Language content is formed based on the students' need in learning a particular language (Cunningsworth, 1995). In this term, BIPA students learn Indonesian language for recreational activity; hence, the materials need to be considered joyful ones. Moreover, language content may also be possible tools to evaluate the suitability of the materials (Cunningsworth, 1995). This research only adopted three out of seven aspects from Cunningsworth's theory (1995); they are themes, topic and vocabulary.

The aim of this research is to investigate and describe the types of cultural content used in Indonesian textbooks in BIPA University of Muhammadiyah Malang (UMM). Given the wide range of language needs among students, it is becoming progressively important to teach Indonesia as a Foreign Language alongside other communication skills such as critical thinking, intercultural knowledge and comprehension, and delicate cultural awareness. Cultural awareness rising can be described as any activity that actively seeks to engage learners and expand their understanding, increase sensitivity, and foster versatility and tolerance of otherness and cultural diversity for the purposes of this study.

\section{Method}

This study applied descriptive qualitative method to analyze the correlation between ER, narrow reading, and a series of article used for teaching BIPA. This method is used to acquire some additional information about the current reading activity in BIPA UMM. To obtain the data, the researcher conducted library research by collecting several journals related to topics and providing sampling articles in current handbook (Figure 1).

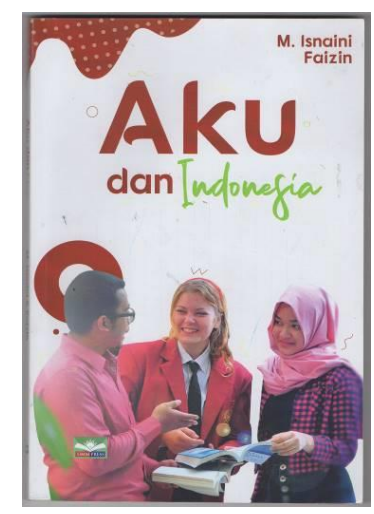

Figure 1 BIPA Textbook Cover 
The main source functioning as the primer data is a handbook which is created and used by BIPA UMM. The book consists of three skills i.e. Speaking, Writing, Reading, and Listening. In each part of skill, it consists of 1 to 6 practices for students. Specifically, in the reading section, the handbook provided reading text which demonstrates multicultural text. Those reading text in the handbook were then analyzed qualitatively by corresponding to the theories.

\section{Result and Discussion}

Teaching BIPA has similarities with teaching English as foreign language. BIPA is learned by many foreigners who never speak Indonesian Language in their daily activity. Referring to the Dixon (2016), teaching foreign language needs the affordable method to give learners long life learning experience. Additionally, teachers in the foreign language classroom are demanded to be creative and given the recreational activity in delivering the materials.

In accordance to characters and principles of teaching BIPA, extensive reading uses the intercultural materials to support narrow reading for adults in improving their reading skill. Narrow reading also emphasizes number of vocabularies authorization to BIPA students. Narrow reading with the series text has close correlation. The narrow reading is possible to be practiced by using series of text to restrict the scope of reading. Since series of the source texts are highly motivating, the authors for storybooks need to consider the content of reading text especially for BIPA students.

The handbook of BIPA UMM entitled Aku dan Indonesia provides a series of reading text which promotes Indonesia culture such as the traditional food, attire, dance, local folklore, local place, and local transportation. In each part of reading text, there will be 1 or 2 task which should be finished by the students. The tasks aim to evaluate the comprehension of the students.

\subsection{Language Aspect}

In writing intercultural reading text, vocabulary as one of the language aspects is crucial since it is a major component in general Indonesian language. As mentioned by Renandya et al., (2018) ER graded reading level referred to the number of vocabularies that could be conquered by students by reading passage. In line with this, the level of vocabulary is adjusted to the readers' level in order to grow the comprehension of readers. Selecting vocabulary is not a simple thing. In writing intercultural reading text, writer needs to provide as much as vocabulary that might be taken from the outside of the classroom. Since Indonesian language vocabulary is so wide, putting the authentic vocabulary from daily activities of BIPA students can stimulate their improvement in reading skill (see Figure 2).

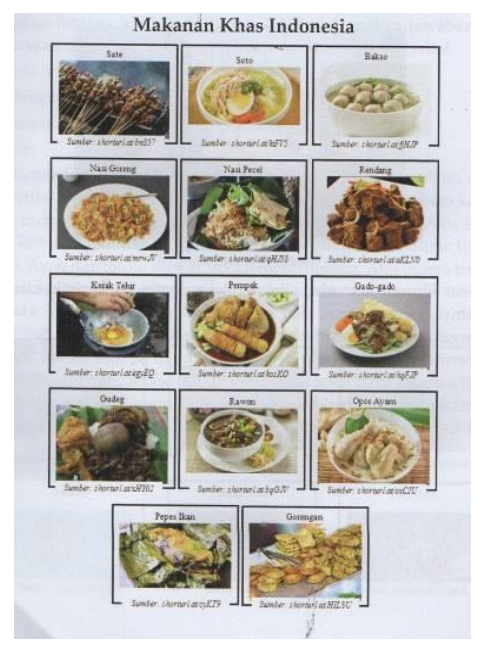

Figure 2 Vocabulary Box

Refer to the use of authentic vocabulary that needs to be considered, writing the series of cultural text for BIPA students also needs to focus on general way in language features, include sentence, cohesion, paragraph, and structure text. Cunningsworth (1998) explained that range word and general language features in a reading text particularly at elementary and low-intermediated level had to be limited. 
Based on the picture, Aku dan Indonesia gives vocabulary boxes attached to pictures to assist the students understand the meaning of vocabulary by guessing the picture (see Picture). In addition, Aku dan Indonesia ensures students understanding in sentence or phrase in form of further reading text by providing dialogue text which has the same topic with the reading text (see Figure 3).

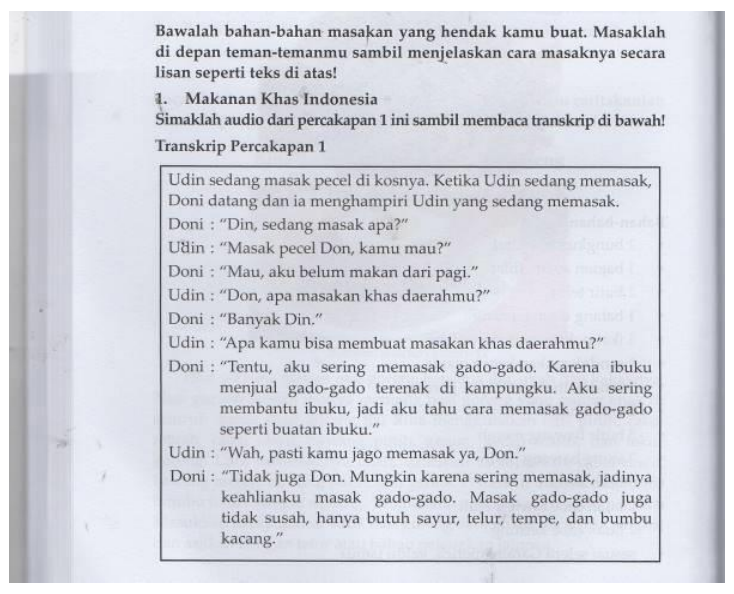

Figure 3 Dialogue Text

Providing a picture to assist the vocabulary in the $A k u$ dan Indonesia called as the material object. Material object is one of the most important subjects of intracultural and intercultural commnication. Every day, students may discuss food, clothes, and housing in some forms or another. The material object provides a particular context and reality in every society, which heavily influences an individual's experience and day-to-day life. It has the ability to affect, paralyze, or stimulate the students as well as generate either positive or negative feelings, in an often-forceful manner during study Indonesia language.

Indonesian does not only focus on language learning, more broadly than that language is a supporting instrument for the formation of the language itself and its continuity in use. Another main reason for implementing intercultural materials into the reading text for BIPA is students shall also find reading enjoyable. According to Lundgren et al. (2009) intercultural competence consists of knowledge, skills, and attitudes which are influenced by the habitual activities. The course materials adopting the intercultural materials should be acquired are as follows:

a. Basic cultural knowledge and general cultural knowledge.

b. Self-knowledge and awareness of others.

c. Personal and social contact awareness

d. Culture has an influence on communication and education, as well as other aspects of life.

e. Discernment on how faith shapes beliefs.

f. Understanding of the living conditions of various communities.

g. Skills in interpreting and relating to others.

h. Discovering and/or communicating abilities.

i. Self-relativizing and other-valuing attitude.

According to the theory, handbook and module for teaching BIPA which already existed provided the intercultural materials. However, not all materials meet the criteria of intercultural materials. In this case, culture is the main item that becomes the core of language from which it is often called subordinate relation. Therefore, integrating language learning material is absolutely connected with culture.

Aku dan Indonesia uses cultural integrated materials, such as connecting material with existing local wisdom. For example, material about tourism vocabulary which has been exemplified by means of tourism in general. This pattern is very common compared to giving examples in form of traditional means of transportation such as horse cart, rickshaw, horse, or others. As for when giving examples with the types of transportation in general, there will be no distinctive value in providing Indonesian language learning. Because after all, teaching Indonesian to foreign students is one of the nation's diplomacy efforts throughout Indonesian.

Using the local vocabulary taken from the local culture plays a substantial role as the 
source of linguistics knowledge of the students (Saraswati, 2017). Therefore, Aku dan Indonesia provides a source text consisting of many local vocabularies that will possibly be utilized by students in their daily activities.

In another example, Aku dan Indonesia materials consist of many vocabularies which adapt from the local language such as ketipung, jedhor, glipang, and kecrek (Figure 4). Those vocabularies will be featured in the same reading text which has same topic. Currently, the text on the handbook covers the point (a) and (d) on the intercultural materials. It shows that the text needs to be developed to at least it has five out of nine.

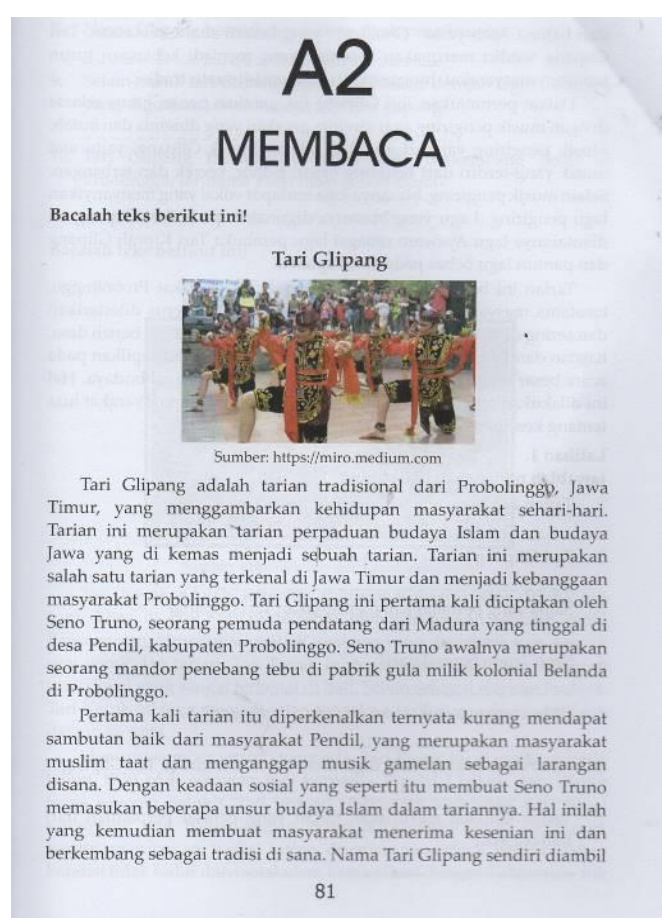

Figure 4 Reading Text in BIPA Handbook

\subsection{Intercultural Communication}

Intercultural communication essentially means communication across different cultural boundaries. Principally the handbook is concerned with the rapidity of reading and comprehension. The level of inquiry and reflection is solely systemic in this case, so that the substance is irrelevant. Aku dan Indonesia has the potential to be very useful in theory and encourages students to expand their thinking and to apply knowledge and ideas in the real world.

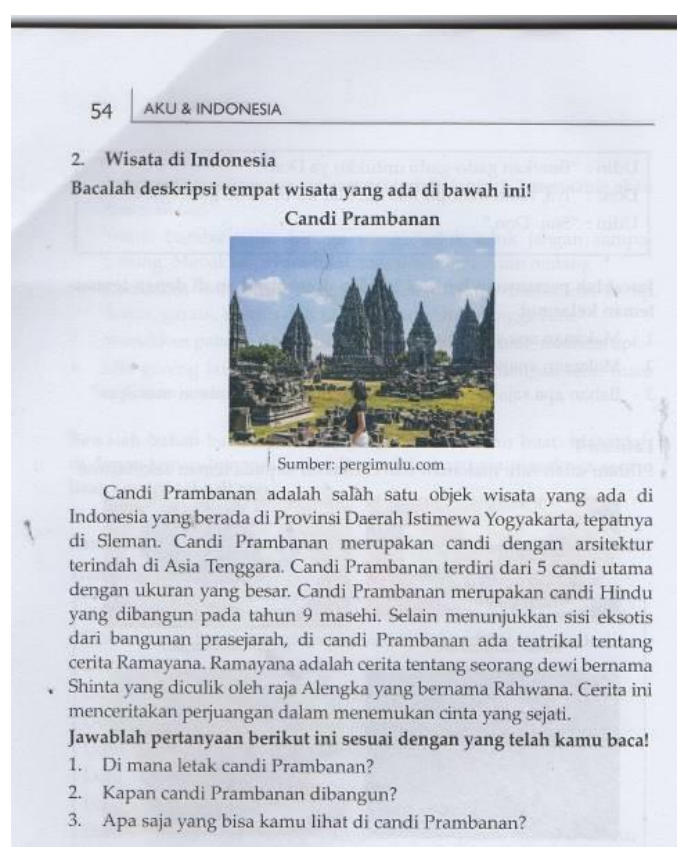

Figure 5 Local Wisdom Source Text

In the reading text above (Figure 5) students are provided with local wisdom story that can lead BIPA students to learn about Indonesia. In addition, BIPA students can apply those wisdom stories in their everyday life because the theme is a manifestation of expression or function. According to Din (2020), intercultural communication which blend in the reading text is possible to train the students' creative thinking skill. Moreover, in foreign language teaching, critical thought has become increasingly necessary. As a result, one of the most essential requirements in the teaching and learning of a foreign language is to develop and enhance the critical thinking skills of its learners.

\subsection{Understanding Culture}

This text (Figure 6) has the same pattern in enhancing cultural comprehension and employs a systemic and empirical approach. The emphasis on actual conversation in the form of dialogue, rather than reading of pure text, is a major difference in this text. Students learn culture and language both subconsciously and consciously. It means schools and teachers, according to Roth (2001) played an important role in training 
students for cultural pluralism. They do so by delivering a curriculum that incorporates different points of view on topics as well as a wide range of positive and negative life experiences, and by inspiring students to recognize the voices that are absent, misconstrued, or misrepresented. It impacts their ability to interact.

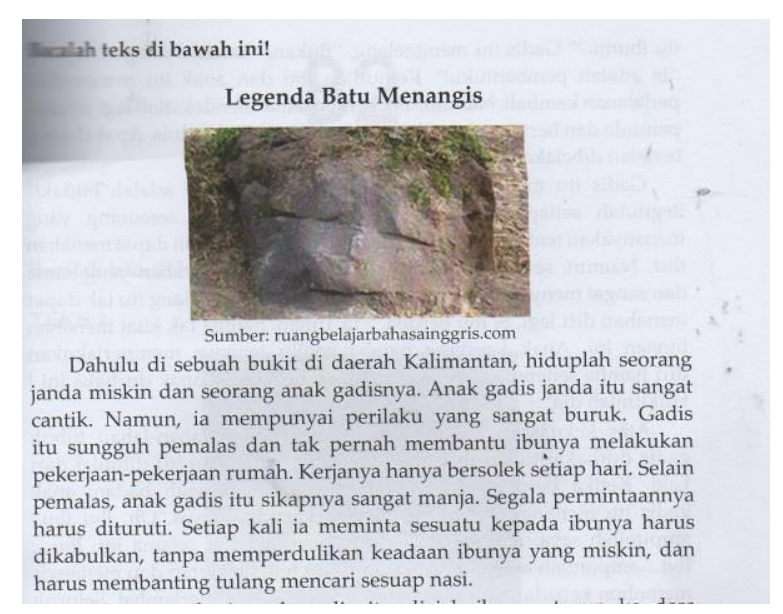

Figure 6 Folklore Text

In addition, based on the research which has been done by Rofiuddin et al., (2019) the chosen reading texts have riled the interest of many BIPA students. Students' language skills develop and they are able to speak Indonesian correctly and accurately when they use the BIPA learning model. Furthermore, when culture is involved in language learning, students can learn to speak and write in acceptable ways, and they deliver positive responses during the teaching and learning process.

In obedience with the previous finding, the cultural themes identified in the authentic texts in the learning paradigm aids students in their language acquisition. It has also been discovered that BIPA students enjoy the entire subjects discussed in the textbook, including linguistic and nonlinguistic elements (Suwono, 2016). The texts were valued according to the needs of the students as well as the learning goals. Its goal is to make students to be able to see, feel, and observe the culture described in the textbook. This combination creates more successful, enjoyable, and fun BIPA learning. It also allows students to use vocabulary independently (Patria, 2019).

\subsection{Students' Need}

The role of knowing students' need is critical in constructing materials. According to ACTFL (2012) students need is the way of teacher to know and be able to do as they learn another language, defining the "what" of language education. In $A k u$ dan Indonesia, the materials were formed based on the National BIPA Syllabus formulated by Ministry of Education and Culture of Indonesia. Nonetheless, in several chosen texts, they were formed based on the teacher's experience in teaching foreigner. One of the most important foundations of teaching and learning practices and procedures is the use of materials to support learners with quick and efficient learning. Having a natural learning experience encourages students to participate in the learning, teaching, and experiencing processes. Language learning is a group endeavour, and without participating in the learning and training processes, it is impossible to learn to communicate, understand, and comment adequately. Teaching resources are vital tools for assisting students in engaging in the learning and teaching processes.

At UMM, where the book is used, the source text aims to help the students who will continue their study at UMM or other place in Indonesia. That theory is the way to shape professional language personality sustaining the process of developing professional identity through language teaching and learning. This is owing to the fact that one's professional identity is established by the creation and updating of one's professional language. Additionally, Bagiyan et al., (2021) found that professional identification was established through future specialist's professional preparation, and was indistinguishably linked to the acquisition of required professional competencies. In the same way as any professional understanding is conveyed by texts that shape a professional 
image of the world, as well as standards and models of behaviour, any professional knowledge is represented by texts. It shows that the students' need in constructing the materials is valuable. More specifically for BIPA students, they can explore their interest after conquering the Indonesia language.

In accordance to the discussion about the language content and language feature, this research proposes writing intercultural reading text has to be done by teachers. The teachers are possible to involve the students to determine kinds of intercultural reading text that will be developed. The teachers have to ask the students to bring any kinds of storybook that they have at home or the teachers invite students to go to library and ask students to choose one or two books to read. The result of the reading may be written in a piece of paper, and then teachers can learn from that writing product to conclude students' level of language content and language features.

Students' need for ER need to be incorporated into the language curriculum. The findings of this study indicate that the majority of L2 teachers faced numerous challenges. This finding implies that ER is not necessary in language learning, and that it is often considered optional if students have other obligations. When L2 teachers include ER in the curriculum, students can be asked to read during class time. This will answer the popular gripe that students do not have enough time to learn.

\section{Conclusion}

Exploring language skills of BIPA students by accommodating Indonesia culture and language aspects through a cultural reading text will be an alternative for improving the communication skills. Additionally, training the students with ER is beneficial since the students can increase their language aspects such as improving the vocabulary and comprehending the structure of Indonesian's sentence. In a nutshell, teaching BIPA students with this method and media can be an effective way to bring recreational activity into the classroom.

The texts studied, for the most part, did not actively involve students. Cultural content and materials were often presented out of context and without any representative or anchoring knowledge that students could use to associate their own culture and experiences to the larger world. While most characters in dialogues and stories are culturally neutral or have an intentional foreign appearance, they all have stereotypical western, North American characteristics, communication styles, beliefs, and attitudes.

Before drawing any conclusions, it is worth noting that the study's scope was limited to Asian countries, so the recommendations above might not be appropriate for ER practitioners in other settings. Teachers from various educational streams or in other contexts may face different challenges since the majority of the respondents were from tertiary institutions. Future research would be required to address unanswered questions resulted from experiences in other countries and contexts. Besides, the next research needs to equip how to construct proper a series of text for the BIPA students. The next research is possible to do the product research of certain book containing materials for BIPA students with the level of reading and vocabularies.

Nevertheless, the ER and narrow reading is possible to be done by the students independently, teacher in BIPA class has a big opportunity to improve the media for teaching to ensure BIPA students learn directly. As the researcher experiences, BIPA students will be more motivated to study if they have a precise guideline to study the language. Finally, but certainly not least, smoothly implementing an ER curriculum can take months or even years which is why teachers should not give up too soon if students do not seem to be engaged.

\section{References}

ACTFL, A. C. (2012). Performance Descriptors for Language Learners. 
https://www.actfl.org/sites/default/file s/pdfs/ACTFLPerformance-

Descriptors.pdf

Bagiyan, A. Y., Shiryaeva, T. A., Tikhonova, E. V, \& Mekeko, N. M. (2021). Heliyon The real value of words : how target language linguistic modelling of foreign language teaching content shapes students , professional identity. Heliyon, 7(February), e06581. https://doi.org/10.1016/j.heliyon.2021 .e06581

Barnett, M. A., \& Krashen, S. (1994). The Power of Reading: Insights from the Research. In The Modern Language Journal (Vol. 78, Issue 3). https://doi.org/10.2307/330145

Cunningsworth, A. (1995). Choosing Your Coursebook (Handbooks for the English Classroom) (p. 153).

Din, M. (2020). Evaluating university students' critical thinking ability as reflected in their critical reading skill: A study at bachelor level in Pakistan. Thinking Skills and Creativity, 35(September 2019), 100627. https://doi.org/10.1016/j.tsc.2020.100 627

Dixon, S. (2016). 100 TESOL Activities for Teachers: Practical ESL/EFL Activities for the Communicative Classroom. Wayzgoose Press.

Ghanbari, M., \& Marzban, A. (2014). Effect of Extensive Reading on Incidental Vocabulary Retention. Procedia - Social and Behavioral Sciences, 116, 3854-3858. https://doi.org/10.1016/j.sbspro.2014. 01.854

Hansen, L., \& Collins, P. (2015). Revisiting the Case for Narrow Reading with English Language Learners. Reading Matrix: An International Online Journal, 15(2), 137-155.
Kiyomi, Y., Atsuko, T., \& Kyoko, O. (n.d.). How Does Extensive Reading Help Japanese EFL Learners Develop GRammatical Knowlegde and Reading Fluency. Extensive Reading World Congress.

Krashen, S. (2004). The Power of Reading. Libraries Unlimited.

Lundgren, U., Guilherme, M., \& Glaser, E. (n.d.). Becoming Interculturally Competent through Education and Training.

Patria, R. R. P. (2019). Indonesia Reading Literacy Progress: an Insight From Pisa Study. Iceap, 195-211. https://doi.org/10.26499/iceap.v0i0.22 1

Reimann, A. (2009). A Critical Analysis of Cultural Content in EFL Materials. Utsunomiya University Faculty of International Studies, 8(28), 85-101. uuair.lib.utsunomiyau.ac.jp/dspace/.../28-8-reimann.pdf?

Renandya, W. (2007). The power of extensive reading. RELC Journal, 38(2), 133-149. https://doi.org/10.1177/00336882070 79578

Renandya, W. A., Krashen, S., \& Jacobs, G. M. (2018). The potential of series books: How narrow reading leads to advanced L2 proficiency. Learn Journal: Language Education and Acquisition Research Network Journal, 11(2), 148-154. http://www.sdkrashen.com/content/art icles/2018_potential_of_series_books .pdf

Renandya, W., \& Chang, A. C.-S. (2017). Current Practice of Extensive Reading in Asia: Teachers' Perceptions. Reading Matrix: An International Online Journal, 17(1), 40-58.

Rofiuddin, A., Susanto, G., Anggari, P., \& Ariani, D. (2019). The Integration of 
Indonesian Culture in BIPA Learning as a Learning Model. January, 0-5. https://doi.org/10.4108/eai.23-32019.2284907

Romijn, B. R., Slot, P. L., Leseman, P. P. M., \& Pagani, V. (2020). Teachers' self-efficacy and intercultural classroom practices in diverse classroom contexts: A cross-national comparison. International Journal of Intercultural Relations, 79(December 2019), $58-70$. https://doi.org/10.1016/j.ijintrel.2020. 08.001

Roth, K. (2001). Material culture and intercultural communication. International Journal of Intercultural Relations, 25(5), 563-580. https://doi.org/10.1016/S0147-

1767(01)00023-2

Saraswati, G. P. D. (Universitas N. S. (2017). Intercultural Communicative Competence (Icc) in Teaching Speaking Material Used in English Department of Universitas Negeri Semarang. Language Circle: Journal of Language and Literature, 11(2), 158-164.

https://doi.org/10.15294/lc.v11i2.958 8

Suwono, H. (2016). School literary movement in Indonesia: Challenges for scientific literacy. Paper Presented at International Conference on Education, 309-317 